\title{
Consumer Attitudes toward SMS Advertising among Jordanian Users
}

\author{
Abdulraheem. M. Ahmad. Zabadi (Corresponding author) \\ College of Business Administration, College of Engineering and Information Technology \\ Jeddah, Kingdom of Saudi Arabia \\ E-mail: Abudlraheem@cba.edu.sa \\ Mohammad Shura \\ College of Business, Middle East University, Jordan, Amman \\ E-mail:mhmadshura@yahoo.com \\ E. A. Elsayed \\ College of Engineering and Information Technology, Jeddah, Kingdom of Saudi Arabia \\ E-mail: elsayed@cba.edu.sa
}

\author{
Received: November 25, $2010 \quad$ Accepted: April 21, $2011 \quad$ Published: February 1, 2012 \\ doi:10.5539/ijms.v4n1p77 URL: http://dx.doi.org/10.5539/ijms.v4n1p77
}

\begin{abstract}
There has been a tremendous growth in the mobile telecommunication industry in Jordan. Jordan has already crossed the 6 million users mark in February 2009 (Arab Advisors Group's, 2010). At the same time, there has also been a growth in the mobile advertising space in Jordan.

Although several papers have been written in the recent times about consumer attitudes towards mobile advertising, a systematic study of these for Jordan context is lacking. This paper has tried to address this need. The underlying paper discusses its relevance and investigates antecedents of consumer attitudes towards SMS advertising via mobile devices and variables influencing it. The analysis is based on a consumer survey. For this purpose a quota sample of 130 cellular phone users in Jordan has been interviewed.

It was found that consumers' perceptions of the entertainment value, Informativeness and credibility of SMS advertisements are positively correlated to consumers' overall attitudes towards SMS advertisements. The study further found consumers' perceptions of the irritation aspect of SMS advertisements is negatively correlated with consumers' attitudes towards SMS advertisements.

The results indicate that attitude toward advertising via mobile devices strongly depends on message Characteristics. The message characteristics need to be developed carefully. Marketers can not only rely on the fact that an advertising message sent via mobile devices will be read and remembered automatically. Also the results indicate that advertising value and advertising message content have the largest impact on attitude toward advertising via mobile devices.
\end{abstract}

Keywords: SMS, Mobile Devices, Consumer attitudes, Advertising, Jordan

\section{Introduction}

SMS has been the most successful non-voice service for mobile operators in the history of telecommunications and, as such, has been a key revenue generator. Every year stories of the demise of this 160-character service are thick in the air, and every year SMS usage continues to grow as more uses are found for this once ignored service. The key to the success of SMS has been its simplicity, reach, price and reliability. All other messaging based applications launched since SMS have struggled to meet the lofty expectations set by the service and pale in comparison to its success. Industry-related reports point to a future in which SMS volumes and revenue will 
continue to grow on a global basis for at least the next three years. So what is going to drive this level of growth? In short, several trends will drive the continued expansion of the service.

Technological advancements have provided various new mediums for advertising to consumers and have further allowed organizations to better reach consumers with regards to the frequency and impact of advertising. Advertisers have to be more creative in the formulation of advertisements and selection of advertising mediums so as to gain the attention of their target market.

The need to create new mediums for advertising has lead to the creation of new-age media such as short message service (SMS) advertising. Before this medium can be effectively used to reach Jordanian consumers, the attitude of consumers towards SMS advertisements need to be determined. This study therefore focuses on determining the perceptions of the Jordan's consumer towards SMS advertisements.

Organizations today operate in an environment that is characterized by constant change and an increase in competition as a result of globalization. (Zyman, 2002), suggest that the biggest change in the market place is that consumers have a greater selection with regards to products and services and those organizations should become more conscious of their advertising efforts. Organizations now view advertising as an investment and tend to value over-communication with consumers, resulting in greater budgets for advertising departments than in the past (Zyman, 2002). Technological advancements have provided various new mediums for advertising to consumers and have further allowed for organizations to better reach consumers with regards to the frequency and impact of advertising (Du Plessis, 2003), These advances in technology, combined with the market place's need to increase advertising to consumers, has led to the fact that "Advertising is everywhere" (G, 2001).

The constant exposure to advertising might cause consumers to become immune to advertising. Advertisers have to be more creative in the formulation of advertisements and selection of advertising mediums so as to gain the attention of their target market (J, 2003). This need to create new mediums for advertising has lead to the creation of new-age media such as: the internet, which includes electronic-mail (e-mail) and websites; wireless application protocol (WAP); voice-over internet protocol (VoIP) and cellular technology and short message service (SMS). WAP is a wireless system that allows users to access the internet using their cell phones. VoIP involves the sending of voice messages over the internet (Du Plessis, 2003).

In 2008, there will be 4.5 million mobile subscribers in Jordan according to a report by BIS Shrapnel cited in the Jordan Times. By September 2005, $41 \%$ of Jordanians had subscribed to mobile services, up from $28 \%$ at the end of 2004, also in Jordan 5, 950, 000101 (101\% of the total population), $85 \%$ among adults 15 years old and above, who own one or more mobile subscriptions (Arab Advisors Group's, 2010) which created the opportunity for a new medium of advertising. Mobile communications and its most successful application, short message service (SMS), now allows for the direct and two-way communication between an organization and consumers.

According to (Yoon, 2001) "Short messaging service (SMS) is a digital cellular network feature and it allows users to send short text and numeric messages to and from digital cell phones using cell phones and e-mail addresses based on public SMS messaging gateways over the internet." Based upon the benefits and proliferation of cell phones, one can expect an increase in the volume of SMS-type advertisements and its importance in the communication mix of an organization. SMS advertising can be classified as traditional advertising, direct marketing or an interactive medium allowing for two-way communication between an organization and customers (Du Plessis, 2003). Organizations are starting to use this medium as a method of sales promotion and send coupons to consumers' cell phones via SMS.

This has proven to be an effective form of sales promotion as consumers have their cell phones on them at all times and have the coupon available when needed (Cravens, 2003), (Dickinger, 2004), (Du Plessis, 2003). In this research SMS advertising will be investigated as a component of the advertising and direct marketing elements.

\section{Development of SMS in Jordan}

SMS is now a very powerful business communication \&marketing tool. We can currently present sending SMS from web. SMS, (Short Message Service), you sending and receiving short textual messages, up to 160 characters for English and 70 characters for Arabic language.

In the Middle East, particularly in Jordan, there are four mobile service providers, and the numbers of subscribers is more than 6 million, slightly exceeding the number of population. In terms of percentage, the mobile penetration in Jordan is $101 \%$ compared to the population (Times, 2009). 
However, although the mobile marketing has a matured rapidly in many European and western countries, it is still infant in many Asian and Middle Eastern countries. Furthermore, most of the previous studies have examined mobile marketing in Western context, and little attention has been paid to the investigation of such strategy in the Arab World. As far the current researcher's knowledge is concerned, no previous studies were found that focus on mobile marketing in eastern countries particularly in Jordan.

More specifically, this is the first empirical research of its kind in the region that tackles in a specific way the attitude of users toward SMS advertising. Another contribution is that the current research draws and systematically synthesizes literature from disparate marketing disciplines, and borrows theories from the social and psychological setting to develop a model which could be used in future studies to measure the influence of mobile marketing on consumers' purchase intention, Based on that, the primary purpose of this paper is to investigate the attitude toward SMS advertising, marketing as a communication tool on generating consumer's positive attitude and to measure attitudes toward such strategy.

Mobile phone penetration in the kingdom reached 103 percent as of the end Mobile phone penetration hits $103 \%$ as of end of September 2010, with $\mathbf{6 . 2 5}$ million subscribers, according to Telecommunications Regulatory Commission figures. Meanwhile, the penetration of rate of land lines reached $\mathbf{8 . 8} \%$, with 514,0000 subscribers, the figures revealed,

E-government program works on providing services to citizens through various communication channels, one of the most important channels is SMS services as push and pull messages, as the most prevalent among the various segments of the Jordanian society. This service is one of the shared services provided by the e-government program for the government entities (Jordan, 2007).

Eid AL ADHA is an occasion for celebration. Recently, it became an occasion for sending SMSs. It is reported that this last Eid, JD 2million were spent on 24milliom mobile messaging in Jordan, country of just over six million people, that is every mobile line owner sent on average four short messages greeting someone on EID (Mansur, 2010).

\section{Significance of the study / study accountability}

Little research has been conducted with regard to consumers' perceptions of SMS advertising and also the impact elements to consumers' via SMS, this is particularly important in the Jordan context where the success of a new medium such as SMS advertising relies on the acceptance of the medium by consumers. Before this medium can be effectively used to communicate with Jordan consumers, research needs to be conducted with regards to their attitudes towards SMS advertising.

The majority of research conducted with regard to consumer attitudes towards mobile or SMS advertising has been conducted in foreign countries where the findings, due to cultural differences and differences in the adoption of technology, may not directly apply to Jordan's consumers. The general consensus among academics and practitioners is that SMS advertising is an ideal medium for reaching consumers.

Proven effectiveness of mobile advertising was clear in three major recent events. First, SMS advertising changing US voters attitudes, SMS marketing firm has published a report showing how voter's attitudes and behaviors are influenced through SMS advertising.

In January 2008, SMS advertising campaigns for democratic presidential candidates Hillary Clinton and Barack Obama delivering over one million SMS impressions across the campaigns. The results of the election suggest that SMS advertising provides a powerful tool for candidates to change consumer's attitudes and voting behavior. The second was its role after the Election Day in Iran. The third in Jordan, SMS advertising has an essential role in choosing $\mathrm{Al}$ Petra as one of the seventh wonders.

Anyhow, SMS messages are flowing day and night to consumers without asking their prior permission to transmitting these messages and this is one of the problems associated with this activity. Other problems emerge from the lack of knowledge about the cultural background of the recipients specially their social, religious, and beliefs standards. In addition to what mentioned above, there is a reasons for us to search in that field, such as the lack of Arabic academic coverage of SMS advertising activities especially in the areas of improving performance and communicating information. Advertising and promotion through mobile phones has been proven the best way taking into consideration the revenue, cost and profit structures in the overall advertising opportunities. 


\section{Research objective}

The main objective of the research is: to determine whether there is a correlation between consumer perceptions of the value of entertainment, Informativeness, irritation and credibility of SMS advertisements and consumers' overall attitude towards SMS advertisements among consumers in Jordan context.

\section{Literature background}

\subsection{SMS advertising}

A key component of mobile marketing communication is advertising, either in a push or pull mode. After obtaining the consumer's permission, push advertising sends relevant but not explicitly requested text and video messages. (Quah, 2002), argue that the push model will dominate mobile advertising since it saves consumers' time and money compared to browsing content.

Short message services (SMS) has become a technological buzzword in transmitting B2C messages to such wireless devices as mobile phones. Many brands and media companies include text message numbers in their advertisements to enable interested consumers to obtain more information. This mode of advertising takes advantage of valuable channels of wireless communication to enhance customer relationships, and to carry out direct marketing and promotional activities (Frolick, 2004). Moreover, multimedia message service (MMS) has provided more visual and active messages. Marketers can benefit from use of photos, music, logos and animation, videos in advertising to consumers' mobile phones. SMS and MMS advertising are expected to achieve higher response rates than e-mail or television advertising, because all advertisements can be sent personally.

When defining SMS advertising, it is first necessary to analyze the definition of mobile marketing as this definition may in part apply to the definition of SMS advertising. (Dickinger, 2004) define mobile marketing as "Using interactive wireless media to provide customers with time and location sensitive, personalized information that promotes goods, services and ideas, thereby generating value for all stakeholders". Mobile marketing is based upon sending information to consumers using either SMS or MMS (Multimedia Message Service) (Kavassalis, 2003).

It can therefore be assumed that mobile marketing involves some degree of SMS advertising with the latter being a component of mobile marketing. For the purpose of this study, SMS advertising will be defined as "Using short message service (SMS), sent to consumers' cell phones, to provide consumers with time and location sensitive information that promotes goods, services and ideas, thereby generating value for all stakeholders" (Kavassilis, 2003).

Studies have highlighted a vast number of advantages of SMS advertising and includes that this medium allows for real-time communication with consumers anytime and anywhere (Tsang, 2004). SMS advertising also increases the probability that the advertisement reaches the target market as consumers generally have only one cell phone which is very personal in nature and carried around with them at all times (Kavassalis, 2003).

SMS advertising is the only channel relevant for recipients when on the move and is a great benefit for targeting young consumers who often have active lifestyles and are not exposed to the more traditional advertising channels (Tsang, M.M, 2004). The younger generations have also been quicker than older generations in learning to use, manage, and adapt to new technologies such as the internet and cell phones (Spero, 2004).

Another benefit of SMS advertising is that, if effectively planned, an SMS advertising campaign is low in cost. The low cost of SMS advertising is amplified by the ability of this medium to target and provide specific customers with relevant information and obtain a high response rate among recipients of the message and reduce wastage (Kavassilis, 2003).

Although SMS advertising has a great advantage over more traditional mediums of advertising, it is often stressed that the medium should not be used in isolation.SMS advertising should be complimentary with the traditional mediums of advertising (Scharl, 2005).

The complementary nature of SMS advertising may be based upon the fact that mobile marketing and SMS advertising are still in the early stages of commercial deployment. Consumers may not as yet be fully adapted to cell phone technology and the receiving of SMS advertisements (Bauer, 2005).

Several studies have been conducted to examine consumer attitudes towards SMS advertising/medium and to measure the effectiveness of SMS advertising. Firstly, (Rettie, 2001), found that the acceptability of SMS is likely to depend on age, income, education and the number of messages received. Secondly, Whitepaper (a) purports that SMS messaging is attractive to younger users, especially for15-24 year's group which has proved extremely difficult to reach with other media (Barens, 2003). Thirdly, (Andersson, 2000), found that a campaign 
did have appositive impact on brand awareness and purchase intention; however, it did not have any effect on brand attitude. Fourthly, (Enpocket., 2002), found that SMS has proven to be an excellent means of communicating brand value: 50\% more successful at building brand awareness than TV and $130 \%$ more successful than radio. Finally, Enpocket found that $94 \%$ of occasions, respondents read the messages, and $23 \%$ of them will show or forward a marketing message to a friend.

\subsection{Consumer attitude}

Attitude is an important concept in research on marketing and information systems. Fishbein defined an attitude as "a learned predisposition of human beings" (Fishbein, 1975). Based on this predisposition, "an individual would respond to an object (or an idea) or a number of things (or opinions)." Kotler stated that "an attitude is a person's enduring favorable or unfavorable evaluations, emotional feelings, and action tendencies toward some object or idea" (Kotler, 2000). Attitude is also an important construct for information systems research. For example, the technology acceptance model that predicts the use of information systems consists of five major constructs: perceived usefulness, perceived ease of use, attitude, intention, and use (Davis, Bagozzi, \& and Warshaw, 1989). Exemplify that permission- based advertising differs from traditional irritative advertising in that messages about specific products, services, or content are sent only to individuals who have explicitly indicated their willingness to receive the message (Tsang, 2004).

Barwise found that $82 \%$ of the respondents mentioned that receiving three permission-based advertising texts per day was "about right", younger customers being more receptive to more frequent advertisements, and the mobile channel has the potential to benefit both advertisers and customers (Barwise, 2002). In formativeness is described as "the ability to inform customers of product alternatives for their greatest possible satisfaction" (Gao, 2006). The Theory of Reasoned Action (TRA) proposes that attitude influences behavior through intention. Intention defined as "the strength of a person's conscious plan to perform the target behavior (Fishbein, 1975).

This study focuses on determining consumer attitudes towards SMS advertisements and it is surmised that the attitude towards SMS advertisements will affect both the success of SMS advertising campaigns and the purchase intentions of consumers who receive SMS advertisements. It was illustrated by (Andersson, 2000), that SMS advertisements and the SMS advertising medium, in general, will affect the attainment of the advertising campaign objectives. Consumer attitudes consist of three components that are cognition, affect and conation according to (DU Plessis, 2007), for the purposes of this study the first component is applicable.

According to Fishbein Attitude Theory (Andersson, 2000), a stimulus, such as an SMS advertisement of a particular brand, has an effect on a consumer's belief system which in turn influences and leads to the consumer developing a specific attitude towards the advertised brand. The attitude which a consumer has with regards to a brand has an impact on consumer's intention to purchase the brand offering.

\section{Research framework}

The framework for the study of consumer attitudes towards SMS advertising relies on the models developed for the study of consumer attitudes towards internet or web advertising and advertising in general, (MackenZie, 1989) (Ducoffe, 1996), developed a model depicting the perceptual antecedents of entertainment, Informativeness and irritation, used to determine consumers' attitudes towards internet advertising identified in the model developed by (Ducoffe, 1996) but it contains two additional constructs namely credibility, which is an antecedent of consumer attitudes towards an advertisement (MackenZie, 1989), and relevant demographic variables which can have an impact on consumer attitudes towards internet advertising (Brackett, 2001).

The framework depicted in (Figure 1) has in the past been used to test consumer attitudes towards SMS advertising (Tsang, 2004) and the constructs entertainment, in formativeness, irritation and credibility will be used in this study to test hypotheses.

\subsection{Hypotheses}

\subsubsection{Entertainment}

Ducoffe (1996), defines entertainment as"...the ability to fulfill an audience's needs for escapism, diversion, aesthetic enjoyment, or emotional enjoyment." The mobile phone has become an important media and entertainment platform. In the mobile entertainment industry, there are lots of entertainment services like listening music, playing games, gambling, watching television, video and sport matches etc., which have set a stage for an explosion of mobile entertainment industry. Entertainment is also a crucial factor for mobile marketing. It is essential that the message is concise and funny, and thus immediately captures consumers' attention (Katterbach, 2002). 
Entertainment Services can increase customer loyalty and add value for the customer. As most people have a natural Playfulness, providing games and prizes via text messaging (SMS) yields high participation. Delivering games and prizes to the customer's cell phone is a successful way to attract and keep customers. Interactive games for example can also be played via text messages. These features can be used to involve customers more deeply and make them more familiar with the advertised service or product (LehmKuhl, 2003). Therefore we conclude that an entertaining advertising message is being perceived more positive by the recipient

Entertainment element in advertising can fulfill consumers' needs for aesthetic enjoyment and emotional release (Ducoffe, 1996). Based on studies of (Bauer, 2005) found that hedonic pleasure (perceived entertainment value) had a positive effect on attitudes towards advertising, the perceived entertainment value of mobile advertisements will be one of the important factor affecting consumers' attitudes toward advertising.

In the study conducted by (Bauer, 2005), the relationship between consumers' perceived entertainment utility of mobile marketing and consumer attitudes towards mobile marketing was tested. The study found that consumers' perceived entertainment utility of mobile marketing has a positive influence on consumers 'perceptions of the overall utility of mobile marketing, which in turn has a positive influence on consumer attitudes towards mobile marketing (Bauer, 2005).

The model of consumer attitudes towards SMS advertisements as developed by (Brackett, 2001) in Figure 1 theoretically depicts the relationship between consumer perceptions of the entertainment value of internet advertising and consumer attitudes towards internet advertising. This model has in various studies been used as the basis for hypothetical testing of the relationship in the SMS advertising or mobile marketing context (Bauer, 2005). Based upon the model, the following hypothesis can be stated:

\section{H1: A high entertainment factor of SMS advertisement is positively correlated to consumers' overall attitudes towards SMS advertising.}

\subsubsection{Informativeness}

In the context of this study, Informativeness can be defined as "the ability of advertising to inform consumers of product alternatives so that purchases yielding the greatest possible satisfaction can be made" (Ducoffe, 1996). The quality of information placed on a company's web site shows a direct influence on the customers' Perceptions of the company and the company's products. Accordingly, information delivered to them via mobile devices also needs to show qualitative features like accuracy, timeliness, and usefulness for the consumer (Siau, 2003). Apart from this, the user needs quick access to the information (s)he is looking for his/her current content of use.

There is even the possibility that information may be delivered automatically to the consumer (Kaasinen, 2003), In any event, consumers want the content of mobile services to be tailored to their interest (Robins, 2003). On top of this, they are interested in getting messages that are relevant for them (Mline, 1993). Information is thus considered a very valuable incentive in mobile marketing because recipients react very positively to advertisement that transfers incentives (Varshney, 2003). Not surprisingly, in formativeness of advertising information is therefore strongly related to the advertising value when it is transferred via traditional media vehicles (Ducoffe R., 1995).

In formativeness can be interrupt as the ability of advertising to deliver information to customers in order to satisfy their needs. The Optimum Stimulation Level Theory states that people aspire to accomplish a certain degree of stimulation and collect information with intrinsic motivation (Hoffman, 1996).Informative content is also essential for Internet advertising; a research finds that the majority of respondents regard the internet as an information source rather than as an environment source (Shavitt, 1999).

The model of consumers' attitudes towards SMS advertisements (Figure 1) illustrates that there is a relationship between consumers' perceptions of the Informativeness of internet advertising and consumers' attitudes towards internet advertising (Brackett LK, 2001).

The model has been used in studies to illustrate that there is a positive correlation between consumers' perceptions of the Informativeness of SMS advertisements and consumers' attitudes towards SMS advertisements (Tsang, 2004) (Brackett LK, 2002).

Based upon the relationship between Informativeness of a SMS advertisement and consumers' attitudes towards the SMS advertisement, the following hypothesis can be stated for this study:

H2: High informativeness of SMS advertisements are positively correlated to consumers' overall attitudes towards SMS advertisements. 
If an advertisement satisfies a consumer's need for information and knowledge about a service or product, it can be assumed that the advertisement will be favorably perceived by the consumer. The study by (Bauer, 2005),supports this assumption and highlights that there is a positive relationship between consumers 'perceptions of the information utility of mobile marketing and consumers' perceptions of the overall utility of mobile marketing. The study further identified the positive association between consumers' perceptions of the overall utility of mobile marketing and consumers' attitudes towards mobile marketing (Bauer, 2005).

\subsubsection{Irritation}

Ducoffe R. (1996), in the context of advertising, defines irritation as: "When advertising employs tactics that annoy, offend, insult, or are overly manipulative". Indignity people feel when being addressed by advertisements has a very great influence on people's attitude toward advertising (Shavitt S. P., 1998). "When advertising employs techniques that annoy, offend, insult or are overly manipulative, consumers are likely to perceive it as unwanted and irritating influence" (Ducoffe, 1996).

"When advertising employs techniques that annoy, offend, insult or are overly manipulative, consumers are likely to perceive it as unwanted and irritating influence" (Ducoffe, 1996). Mobile advertising may provide an array of information that confuses the recipient and can be distracting and overwhelming the consumer with information (Stewart, 2002 ). Consumers may feel confused about them and react negatively. Another point of possible annoyance is unwanted messages, commonly known as spam (Dickinger, 2005), Spam intrudes into consumers' privacy and stifle consumer acceptance. We therefore conclude that irritation caused by an incomprehensive or unwanted mobile advertising message may reflect negatively on the perceived advertising value of mobile marketing.

The relationship between consumers' perceptions of the irritation of an advertisement and consumers' attitudes towards an advertisement is theoretically supported by the attitude model developed by (Brackett LK, 2002) (Tsang, 2004), tested the relationship between these two constructs and found that consumer perceptions of the irritation of SMS advertisements are negatively correlated to consumer attitudes towards SMS advertisements. The following hypothesis can therefore be stated:

\section{H3: Irritation of an advertising message is negatively correlated to consumers' overall attitudes towards SMS advertisements.}

\subsubsection{Credibility}

Advertisement credibility has been defined by (MackenZie, 1989), as "the extent to which the consumer perceives claims made about the brand in the ad (advertisement) to be truthful and believable." Advertising credibility turned out to be significantly relevant to advertising value of web advertising (Brackett LK,, 2002), Define advertising credibility as "consumers' perception of the truthfulness and believability of advertising in general", whereas (Stewart, 2002), refer to it as "predictability and fulfillment of implicit and explicit requirements of an agreement" (online document). Credibility of an advertisement is influenced by different factors, especially by the company's credibility and the bearer of the message (Gold smith, 2000).

But it is also influenced by the advertising medium. For example, Marshall and (Yang, 2007) found out that a message on the Internet achieves less credibility than a printed message unless the message is communicated by a strong brand. There is no empirical evidence on the overall credibility of messages transferred to mobile devices and their influencing factors. Considering the findings cited above we conclude that the credibility of a mobile advertising message has a positive influence on consumers' attitude toward advertising via mobile devices and on the perceived advertising value of the consumer.

The theory of psychological reactance suggests that people react adversely when they perceived their freedom of choice is being threatened. When people feel that advertising is annoying or irritating, they will probably express their irritation by developing unfavorable attitudes towards receiving advertising. People would also tend to maximize their benefits or utilities by reducing the cost, i.e. the irritation caused by the advertising (Brehm, 1972 ).

Consumers' attitudes towards SMS advertisements (Figure 1) further support the relationship between consumer perceptions of the credibility of the advertisement and consumer attitudes towards the advertisement (Brackett, 2001). Research conducted by various researchers has identified that there is a positive correlation between consumer perceptions of the credibility of an advertisement and consumer attitudes towards the advertisement (Brackett, 2001). The following hypothesis can therefore be stated with regards to the constructs:

H4: High credibility of SMS advertisements are positively correlated to consumers' overall attitudes towards SMS advertisements. 
Relevant Demographic Variables: besides the above-mentioned influencing factors that are mainly related to the message and its attributes itself as well as to related privacy issues, we also assume that demographic variables also can affect perceived advertising value and attitude toward advertising.

\subsubsection{Age}

Generally, young people are heavy users of mobile services (Dickinger, 2005). For them mobile devices have become as much as a fashion accessory as they are a communication device (Robins, 2003). Younger consumers also show a more favorable attitude toward traditional advertising in a number of dimensions. They like looking at ads and they feel more comfortable when doing so (Shavitt S. P., 1998). Not surprisingly, they also show a very positive attitude toward mobile ads, whereas older consumers are also positive about mobile ads, but more prudent (Kaasinen, 2003). Considering these facts we come to the conclusion that younger consumers value advertising messages via mobile devices to a higher extent than older consumers and also show a more positive attitude toward then, the following hypotheses can be stated:

\section{H5: Age of the consumer is negatively correlated with a "positive" attitude toward SMS advertising via} Mobile devices.

\subsubsection{Gender}

Gender has shown to be relevant in forming overall attitudes on mobile phones. Women and men perceive mobile phones and their usage differently (OZhan, 2004). Ling reports that the role of the mobile phone differs between genders (Ling, 2001), Generally male consumers show a more favorable attitude toward ads than female consumers (Shavitt S., 1998). Since there is so far no research done on the attitude of the genders toward advertising via mobile devices, we can only conclude that there are differences in their attitude toward this form of marketing and its value. The following hypothesis can therefore be stated with regards to the constructs:

\section{H6: Attitudes toward SMS advertising via mobile devices differ between men and women.}

\subsubsection{Education}

OZhan (2004), reports that as educational level increases, the level of negative attitude toward mobile phones increases also. These findings are supported by Saker and (Saker, 2003), who consider economic conditions as an influencing factor on adoption and usage of mobile phones (Saker, 2003). Persons with less education and lower income generally report a more favorable attitude toward advertising in general (Shavitt S., 1998). Lowery and We therefore conclude that interviewees with a higher level of education show a more negative attitude toward advertising via mobile devices and perceive a lower value. The following hypotheses can be stated regards to the consumers:

\section{H7: A high level of education is negatively correlated with a "positive" attitude towards SMS advertising via mobile devices.}

\subsubsection{Advertising value}

Advertising value is a measure for advertising effectiveness and "may serve as an index of customer satisfaction with the communication products of organizations". It is defined as "a subjective evaluation of the relative worth or utility of advertising to consumers" (Ducoffe R., 1995). A value can be described as an enduring belief that a specific conduct or state is personally-psychologically or socially-culturally preferable to a converse mode of conduct or an opposite end state of existence (Levi, 1990). Value potentially derives from the expectations about an offering itself, from experiences accompanying the exchange, and from the residual of having engaged in behaviors necessary to achieve the exchange. Hence, value can reflect the worth of the element itself as well as the experience associated with the transaction (Houston, 1987).

Values are the basis of actions, attitudes, and judgments in advertising as well as in other aspects of social life (Beatty, 1985). Advertising value of web advertising has shown to have a significant influence on attitude toward web advertising (Ducoffe R., 1996). We thus conclude that a highly perceived value of advertising via mobile devices also reflects positively on the consumers' attitude toward advertising via mobile.

\subsection{Methodology}

\subsubsection{Population}

The target population for the study includes all Consumers, over 16 years old in the city of Amman, who own a cell phone and have in the past received and sent an SMS advertisement from an organization advertising a product or service. 


\subsubsection{The sample}

In the sampling Stage the study is based on a convenience sample of 150 consumers living in Amman. 150 questionnaires were distributed randomly in three big Shopping centers in Amman; Safeway, Mecca mall, and Abdoun Mall, approximately 50 questionnaires were distributed to each Mall using drop and collect method. Participants were briefed about the purpose of the study, and given enough time to fill out the questionnaire. 135 questionnaires were collected; five of those were discarded because they were incomplete. 130 found usable for this study. Table 1 shows the distribution of demographic characteristics of the sample.

\subsubsection{Research tool}

The primary data was collected through a self administrated questionnaire which was originally developed for this purpose. The survey Questions was tested with 20 consumers to determine the face validity and clarity. A complete questionnaire was developed based on the comments collected during the pre-testing period. The entertainment, Informativeness and irritation scales used in the study were adapted from Ducoffe's (1996) study of consumer attitudes towards advertising on the World Wide Web. The credibility scale was adapted from the scale developed by (Brackett and Carr, 2001) in the study of consumer attitudes towards web advertising. For the purpose of this study the wording of scale items was slightly adapted to be more in line with consumer attitudes towards SMS advertising.

A five-point Likert-type scale of agreement, running from strongly agree to strongly disagree $(1=$ strongly disagree, 3 is the midpoint of the scale, and $5=$ strongly agree was used employed to measure customer attitudes towards mobile advertising. Before the questionnaire was conducted, it was pretested on ten mobile phone users in order to measure the construct the validity of the attitude measurement. Further, the questionnaire validated through a number of specialists in this field, there comments were considered in the final version. (Appenix1).

\subsubsection{Data reliability}

The attitude data were first tested for reliability using Cronbach's alpha to assess data reliability, the Cronbach's alpha values for the constructs are summarized in Table 2. As most research method guides treat a value higher than (0.7) acceptable level of internal consistency, and suitable for further analysis, which is generally acceptable in scientific research.

\section{Data analysis and discussion of results}

For analysis purposes, the agreement scale was regrouped into three categories as Agree, Neutral, and Disagree. Several statistical techniques were used to satisfy study objectives, including frequency analysis, descriptive analysis, mean and standard deviations of questions used in Likert scale were calculated, and t- test, at $\quad \alpha<0.001$, $\alpha<0.01$ ) significance level, were used for testing the five hypotheses ( $\mathrm{H} 1$ to H5). The average of respondent score on overall attitude was $2.70, \mathrm{SD}=0.67$ on five - point Likert scale, this below the neutral score of $3(\mathrm{t}=6.74$, $\rho<0.001$ ), which implies that respondent attitudes toward SMS advertising were negative. A correlation analysis indicates that all four attributes of SMS advertising are significantly related to the overall attitude toward SMS advertising. Entertainment, Informativeness, and credibility are positively correlated to overall attitude, where as irritation is negatively correlated to the overall attitude (Table 3).

The attributes are themselves significantly correlated; regression analysis is used to differentiate their individual contributions, results shows that entertainment is the major factor that affects the overall attitude with contribution of $45.5 \%$ of the variance. Credibility is the second important factor with contribution $8.7 \%$. Informativeness and irritation have marginal contributions of $1.9 \%$ and $0.6 \%$ respectively. Table 4 shows the results.

A total of 150 questionnaires were distributed, and 130 of them were returned. The respondents included 69 (53\%) males and $61(47 \%)$ females. Fifty - five percent of them were under 30 years of age. Eighty - three percent of them were a student, which indicates that the respondents' were primarily young and well educated. Most of them were heavy users of SMS, they form a good target group of mobile advertising. Eighty - nine percent of respondents read the received mobile advertising messages right away. More than $92 \%$ of the respondents had more than 4 years of experience using mobile phones.

In Table 5 the number of SMS messages sent and received by the respondents is illustrated (per day). The findings in Table 5 suggest that the respondents are involved to a great extent with the SMS communication function of their cell phones and are experienced with the usage of cell phones and, more specifically, the SMS function. The findings imply that a respondent through their high level of involvement with their cell phones depends on it as a means of communicating with friends and possibly advertisers. 


\subsection{Hypotheses test}

The first hypothesis (H1) investigated whether or not there is a positive correlation between consumers' perceptions of the entertainment value of SMS advertisements and consumers' overall attitudes towards SMS advertisements. Tables 3 , and 4 , indicates the result of the hypothesis test. The resulting p-value $(p<0.001)$ is less than 0.05 . And therefore the hypothesis can be accepted. The hypotheses were supported by data. The high correlation coefficients indicate that there is a strong relationship with advertising value as well as consumers' attitudes toward it. There is therefore a positive correlation between consumer's perceptions of the entertainment value of SMS advertisements and consumers' attitudes towards SMS advertisements. This implies that management need to consider the entertainment aspect of SMS advertisements sent to consumers. Delivering games and prizes to the customer's cell phone is a successful way to attract and keep customers.

The coefficient of determination $\left(\mathrm{R}^{2}=0.455\right)$ implies that 45.5 percent of the variance in consumers' attitudes towards SMS advertisements can be explained by the variation in consumers' perceptions of the entertainment value of SMS advertisements,

The second hypothesis (H2) investigates the correlation between consumers' perceptions of the Informativeness of SMS advertisements and consumers' overall attitudes towards SMS advertisements. Informativeness of the advertising message turns out to be the third strong influencing factor on consumers' perceived advertising value, but shows the strongest influence on consumers' attitude.

The coefficient of determination $\left(\mathrm{R}^{2}=0.019\right)$ implies that 1.9 percent of the variance in consumers' attitudes towards SMS advertisements can be explained by the variation in consumers' perceptions of the entertainment value of SMS advertisements,

Hypothesis $\mathbf{3}$ is concerned with testing whether or not there is a negative correlation between consumers' perceptions of the irritation of SMS advertisements and consumers' overall attitudes towards SMS advertisements. This hypothesis predicts irritation to be negatively associated with virtual advertising value. Results indicate that irritation does negatively influence the value of mobile advertising. A low correlation coefficient indicates that influence of irritation is not as strong as the influence of the variables entertainment and Informativeness.

The $\mathrm{p}$-value $(\mathrm{p}<0.001)$ is significant at the 0.05 level and the alternative hypothesis can be accepted. The coefficient of determination $\left(\mathrm{R}^{2}=0.006\right)$ implies that nearly 0.6 percent of the variance in consumers' attitudes towards SMS advertisements can be explained by the variation in consumers' perceptions of the variance in consumers' attitudes towards SMS advertisements can be explained by the variation in consumers' perceptions of the irritation of SMS advertisements.

Hypothesis $\mathbf{4}$ is concerned with testing whether or not there is a positive correlation between consumers' perceptions of the credibility of SMS advertisements and consumers' overall attitudes towards SMS advertisements. Hypotheses indicate that a high credibility of the advertising message is positively associated with overall attitude towards SMS advertising. This hypothesis could also be confirmed. The correlation coefficient shows a strong relationship between the advertising value and perceived credibility.

The $p$-value $(p<0.001)$ calculated for the test is significant at a $95 \%$ level of confidence $(p<0.05)$. The hypothesis can therefore be accepted (Table3). The coefficient of determination $\left(\mathrm{R}^{2}=0.87\right)$ implies that, nearly 8.7 percent, although there is a positive correlation between consumers' perception of the credibility of SMS advertisements and consumers' overall attitudes towards SMS advertisements.

Hypotheses 5 to 7 dealt with relevant demographic variables of the consumer. Hypotheses 5 state that the age of the advertising recipient reflects on the perceived advertising value and on their attitude toward SMS advertising via mobile devices. Surprisingly, these hypotheses could not be supported. Age does not influence the advertising recipients' perception of mobile marketing significantly.

Hypotheses 6 indicated that gender influences both of the dependent variables. Neither of the hypotheses could be supported. There were no significant differences found in neither perceived value nor in attitude SMS toward advertising via mobile devices.

Hypotheses 7 proposed that a higher education level is positively associated with the dependent variables. Only hypothesis $10 \mathrm{a}$ could be supported. Interviewees with higher education did not show a more positive attitude toward advertising via mobile devices, but did perceive it as more valuable. These results are also supported by (Brackett, 2001) findings. 
The results of the hypotheses tests indicated that consumers' perceptions of the entertainment value, Informativeness and credibility of SMS advertisements are positively correlated with the consumer attitudes towards SMS advertisements, so hypotheses 1 and 2 as well as 4predict that entertainment and Informativeness and credibility are positively associated with advertising value when addressing consumers via mobile devices. Both hypotheses were supported by data. The high correlation coefficients indicate that there is a strong relationship with advertising value as well as consumers' attitudes toward it (Brehm, 1972). This is consistent with the findings of (Tsang, 2004) in their study of consumer attitudes towards SMS advertisements. Tables 3 and 4 show the results.

A major finding is that consumers have fairly negative attitudes towards SMS advertisements. It is suggested that the framework developed by (Brackett, 2001) be applied to consumer attitudes towards SMS advertisements in Jordan context. The findings indicate that the Jordanian's consumers' are highly engaged in the use of cell phones and the SMS functions, as a means of communicating with others.

\section{Limitations}

While the study provides useful theoretical and managerial contributions on understanding factors influencing consumers' attitudes to mobile advertising, there are some limitations when interpreting the results. More importantly, these limitations must be addressed and taken into consideration before constructing any generalizations. New research directions can be derived from these limitations.

The study is limited by first; the data were collected in a convenience sampling at big shopping centers in Amman, which may have resulted in sampling biases. Majority of the respondents were young people, because an older people do not go to big shopping centers as often as young ones. Second, a relatively small sample of participants $(n=130)$ were selected using non probability sampling, this limitation makes it difficult to generalize and apply the findings of this study. Third, our study doesn't deal with the problem of SMS permission - based advertisements.

The final limitation of the study is that the overall attitude construct was measured on one item. The scale may not be a very accurate measurement of consumers' overall attitudes towards SMS advertisements. Despite pre-testing and proper evaluation to ensure reliability, there have been semantic and linguistic biases in translation from English to Arabic. Overall the previous limitations, the major one is, despite of widespread occurrence of cell in Jordan, but few if not non-existing studies dealt with this subject.

\section{Conclusions}

The study discussed in this paper investigated consumer attitudes about receiving SMS advertisements. In the light of the overall findings in the current research, this study concludes that, in general as the empirical data show, the respondents held negative attitudes about receiving mobile advertisements. This may have been because they found mobile advertisements irritating. Entertainment was the most significant of the factors affecting respondents' attitudes, followed by credibility and Informativeness.

Overall, the findings show us that consumers' perceptions of SMS advertising are rather negative. The negative attitude toward SMS advertising, especially when unfavorable, implies that marketers have a lot of work to do to make SMS advertising more popular and attractive., In addition, the study opens a new channel of communication on multiple unexamined matters concerning the mobile advertising industry.

The results indicate that attitude toward advertising via mobile devices strongly depends on message characteristics. The message characteristics need to be developed carefully. Marketers can not only rely on the fact that an advertising message sent via mobile devices will be read and remembered automatically. The mobile device may be an attention getter, but an attention getting device that is unrelated to the message will not attract consumers' interests in the message or the product. This creates new challenges for marketers in the future.

\section{Recommendations for future research}

In the light of the current research findings and conclusions, the study recommends that, future researchers could use a bigger sample of respondents and where possible make use of random sampling when selecting respondents to participate in the study. Future researchers should also develop a new scale to measure overall attitudes towards SMS advertisements, which incorporates more items.

Furthermore, special efforts may have to be made to know what factors really contribute to negative attitudes toward mobile advertising, and how attitudes can be changed. Practitioners may use the findings to design marketing programs with mobile advertisements that create positive attitudes and avoid possible negative effects. 
The Issue Permission based marketing, the sending of SMS advertisements to only those who have agreed to receive promotional information, is an important element for the success of SMS advertising. It should be considered in future researches.

\section{Contribution and implications}

The theoretical contribution of this study lies in outlining the key factors that influence consumers' attitudes toward SMS advertising. Mobile advertising is an unprecedented way of marketing communications (Asil, 2007). Nevertheless, low acceptance rate will hinder the success of mobile advertising campaigns.

Based upon the consumers' negative attitudes towards SMS advertisements, marketers need to recognize that SMS advertisements, although offering many benefits in terms of reaching the customers, may not be as effective in creating favorable attitudes towards the advertised product or service. Consumers with negative attitudes towards SMS advertisements may choose to ignore, and not pursue the information of the SMS advertisement. Marketers will find it difficult to create awareness of a product or service when using SMS advertisements to consumers with negative attitudes towards the medium.

With regard to the fairly positive perceptions of the entertainment value of SMS advertisements, marketers need to look at ways of increasing the entertainment as well as the level of enjoyment consumer's associate with the receiving of SMS advertisements.

In order to overcome the screen size and entertainment limitations of SMS messages, marketers need to perhaps make use of the MMS (multimedia message services), which takes SMS messages to the next level and allows for the inclusion of visual elements, such as pictures and videos, as well as sound. The use of MMS can help marketers create more unique and entertaining advertisements that can be sent to consumers' cell phones (Dickinger, 2004), (Okazaki, 2005). Marketers should also look at creating humorous SMS advertisements as these can help to gain the attention of readers (Barwise, 2002). This would however require greater and more accurate capturing of consumer information so as to determine the consumers who have MMS enabled cell phones. The relationship between consumers' perceptions of the irritation of SMS advertisements and consumer attitudes towards SMS advertisements, suggests that marketers need to ensure that messages are sent to consumers at a reasonable time during the day. A recommendation is that marketers only send SMS advertisements to recipients between 09:00 and 19:30 on weekdays and when sending SMS advertisements to students, avoid sending the advertisement before noon as students may be in class or sleeping (Dickinger, 2004).

Respondents' perceptions of the credibility of SMS advertisements proved to be relatively negative which will have an adverse effect on consumers' attitudes towards SMS advertisements.

It is essential, for the success of an SMS advertising campaign, to first gain the permission of consumers before sending SMS advertisements to random consumers (Andersson A, 2000; Kavassilis, 2003; Nysveen H, 2003; Leppäniemi M, 2005), add that SMS advertising "is considered more acceptable when delivered by a trusted source as opposed to an unknown one."

For advertisers as well as media and marketing professionals, the managerial implications of this study are to help them better understand mechanisms and factors leading to more effective mobile advertising campaigns. Without encouraging mobile users to first accept mobile advertising, it is difficult to ensure mobile advertising will be processed.

Although mobile advertising adoption and acceptance is on the rise, without an unambiguous understanding of the fundamentals affecting consumers' responses' to mobile advertising, mobile marketing and advertising professionals will have a limited power to constantly generate positive and effective yields from their programs.

Overall, it's clear that mobile advertising is going to be the future trend. Practitioners need to have a better under-stand the target audience for SMS advertising campaign and send messages to consumers whereby the language and content of the SMS advertisement is in unison with the target audience's profile and expectations. Marketers need to further ensure that they send only relevant information to targeted consumers. Consumers value SMS advertisements that are short, straight to the point and concern information that is relevant to their interests. Advertising companies are well advised to carefully design their mobile advertising messages and also plan their mobile advertising campaigns and target groups thoroughly.

Findings provide evidence supporting earlier literature that to be successful in SMS campaigns, messages need to be relevant, highly targeted, personalized and of value added content. Although respondents showed a fairly neutral support for text advertising, mobile marketers should be delighted with a strong support for permission-based mobile marketing efforts. The mobile user attitudes might be improved over time if the permission concept is put into practice. 


\section{References}

Andersson A. Nilsson (2000). Wireless Advertising Effectiveness,Evaluation of an SMS advertising Trial. [Online] Available: http//web hhs.se/cic/cources/underbridge /wireless_ad_eff pdf

Arab Advisors Group's. (2010, March). [Online] Available: http://www.arabadvisors.com

Asil, Vatanparast (2007). International Journal of Mobile Marketing, 2 (2), 21 - 34.

Barens, S., \& Scornavacca, E. Jr. (2003). Mobile marketing :the role of permission and acceptance. Proceedings of Second International Conference on Mobile Business. Vienna, Austria.

Barnes, S.J. (2002). Wireless digital advertising: nature and implications. International Journal of Advertising, 21 (3), 399-420.

Barwise, P., \& Strong, C. (2002). Permission - based mobile advertising. Journal of Interactive Marketing, 16 (1), 14 - 24. http://dx.doi.org/10.1002/dir.10000

Bauer, HH., Barens, SJ., Neumann MM., \& Reichardt, T. (2005). Driving consumer acceptance of mobile marketing: A theoritical framework and empirical study. J,Elect.Commerce, Res. 6(3), 181 - 192.

Beatty, SE., L. R. Khale, P., Homer and M., Shekar. (1985). Altrnative Measurement Approaches to Consumer Values: The list of Values and the Rokeach Value Survey. Psychology and Marketing, 2 (3), 181 - 200. http://dx.doi.org/10.1002/mar.4220020305

Brackett, L.K., and Carrs, B.N. (2001). Cyperspace advertising vs, other media: Consumer vs mature student attitudes. Journal of Advertising Research, 41, 5, 32 - 32.

Brehm, J. (1972). Response to Loss of Freedom: Theory of Phychological Reactance. New York: Academic Press.

Chaffey, D. (2004). E- Business and E- Commerce Management. London: Prentice Hall,

Cravens DW., \& Piercy NF. (2003). Strategic marketing (7th edn). New York: Mc Graw Hill.

Davis, F.D., Bagozzi, R.P., and Warshaw, P.R. (1989). User acceptance of computer technology: Acomparison of two theoritical models. Management Science, 35, 8, 982-1003. http://dx.doi.org/10.1287/mnsc.35.8.982

Dickinger A., Haghirian P., Murphy J., \& Scharl A. (2004). An investigation Conceptual model of SMS marketing. Proceedings of the Thirty Seventh Hawaii International Conference of System Sciences. (pp. 1 - 10). Hawaii.

Dickinger, A. S. (2005). Diffusion and success factors of mobile Marketing. Electronic Commerce Resaerch and Applications, 4 (2), 159 - 173. http://dx.doi.org/10.1016/j.elerap.2004.10.006

DU Plessis P.J., \& Ropusseau G. (2007). Buyer Behavior (4th edn). Capetown: Oxford.

Du Plessis, Bothma, Jordaan, and Van Heerden (2003). Integrated marketing Communication. Claremont: New Africa Books.

Ducoffe, R. (1996). Advertising Value and Advertising on the Web. Journal of Advertising Research, 36 (September/October), $21-36$.

Ducoffe, R. (1996). Advertising value and advertising on the websites. Journal of Advertising Research, 465, 21 -35 .

Ducoffe, R. (1995). How consumers Assess the Value of Advertising. Journal of Current Issues and Research in Advertising, 17 (1 (Spring 1995)), $1-18$.

Enpocket. (2002, June 19). The response Performance of SMS Advertisiong. [Online] Available :http://enpocket.com

Fishbein, M., and Ajzen, I. (1975). Belief, Attitude, Intention and Behavior: An Introduction to Theory and Resaerch, Reading. MA: Addison-Wesley.

Frolick, M.N., and CHEN, L.D. (2004). Assessing Mobile Commerce OIpprtunities. Information Systems Management, 21(2), 53 - 61. http://dx.doi.org/10.1201/1078/44118.21.2.20040301/80422.8

G., Cook. (2001). The discource of advertising (2nd edn). New York: Routledge.

Gao, Y. (2006). Perceptual antecedents of user's attitude in electronic commerce. The DATA BASE for advances in Information Systems, 37(273), 42 - 50. 
Gold Smith, R. (2000). The impact of Corporate Credibility and celebrity on consumer reaction to advertisements and brands. Journal of Advertising, 29 (3), 43 - 54.

Heinonen K. S. (2002). Consumer responsiveness to marketing communication in digital channels. [Online] Available: http://www.hkkk.fi/netcomm/Imglib/2/66/Heinonenand strandvick. (April 7th, 2006).

Hoffman, D. (1996). Marketing in hypermedia computer - mediated environments: Conceptual foundations. Journal of Marketing, 60 (3), 50 - 68. http://dx.doi.org/10.2307/1251841

Houston, F.S., and J.B.Gassenheimer. (1987). Marketing and Exchange. Journal of Current Issues and Research in Advertising, 51 (October), 3 - 18.

J, Capoo (2003). The future of advertising new media, new clients, new consumer in the post-television age. New York: Mc Graw Hill.

Jordan, E-Government (2007). [Online] Available: www.jordan.gov.jo/wps/portal

Kaasinen, E. (2003). User Needs for Location - aware of Mobile Services. Personal and Ubiquitous Computing, 7, 70 - 79. http://dx.doi.org/10.1007/s00779-002-0214-7

Katterbach, W. (2002). Die SMS - VerKaufer. Impulse, February Ist, 67.

Kavassalis P., Spyropoulou N., Drossos D., Mitrokostas E., \& Gikas G., Hatzistama. (2003). Mobile Permission Marketing: framing the market inqiury. Int. J, Elect. Comer, 8 (1), 55 - 79.

Kearney, A. (2002). Mobinet Index, no.5. Chicago: Kearney and Campbridge University.

Kotler, P. A. (2002). Principles of Marketing : European edition. London: Prentice Hall.

Kotler, P. (2000). Marketing Management. London: EngleWood Cliffs, NJ: Prentice Hall.

Kotler, P. (2003). Marketing Management: Upper Saddle River. New Jersey: Pearson Education.

Krishnamurthy, S. (2003). E- Commerce Management, Mason. Ohio: Thomson, South Western.

LehmKuhl, F. (2003). Kusse Und Machotests. FOCUS, January 6th, 2003.

Levi, S. (1990). Values and Deeds. Applied Psychology: An International Review, 39 (4), 379 - 400.

Ling, R. (2001). We Release Them Little by Little :Maturation and Gender Identity as seen in the Use of Mobile Technology. Personal and Ubiquitous Computing, 5, 123 - 136. http://dx.doi.org/10.1007/s007790170015

MackenZie, S. R. (1989). An Empirical Examanation of the Structural Antecedents of Attitude Toward the Ad in an advertising pretesting Context. Journal of Marketing, 53 (April, 1998), 48 - 65.

Mansur, Y. (2010). The Blessed SMS sarcrifice. The Jordan Times.

Mline, G. M. (1993). Direct Mail Privacy - Efficiency Trade - Offs within an Implied Social Contract Framework. Journal of Public Policy \& Marketing, 12 (2), 206 - 216,

Okazaki. (2005). Mobile advertising adoption by multinationals: Senior executives'initial responses. J.Internet Res. 15 (2), 160.

OZhan Dedeoglu, A. (2004). The Sympolic Use of Mobile Technology Among Turkish Consumers. Journal of Euro - Marketing, 2 (3), 143 - 162.

Petty, R. (2003). Wireless advertising messaging: Legal analysis and public policy issues. Journal of Public Policy \& Marketing, 22 (1), 71 - 82. http://dx.doi.org/10.1509/jppm.22.1.71.17627

Quah, J.T.S., and LIM, G.L. (2002). Push selling - Multi cost messages to wireless devices based on the publish /subscribe model. Electronic Commerce Research and Applications, 1 (3 - 4), 235 - 246.

Rettie, R., and Brum M. (2001). M-Commerce: The Role of SMS text Messages, In the proceedings of the fourth biennial International Conference on Telecommunications and Information Markets (COTIM2001). Karlsruhe, Germany.

Robins, F. (2003). The Marketing of 3 G. Marketing Intelligence \& Planning, 370 - 378.

Saker, S., and J. D.Wells (2003). Understanding Mobile. Communications of the ACM, 46 (12), 35 - 40,

Scharl A., Dickinger A., Murphy, J., \& Scharl A. (2005). [Online] Available: http//o-web.biz.uwa.edu.au.innopac.up.ac.za:80/staff/Jmurphy /ECRA-2005

Schlosser, A., Shavitt, S., \& and Kanfer, A. (1999). Survey on Internet User's attitudes toward Internet advertising. Journal of Interactive Marketing, 13, 3, 34 - 54. 
Shavitt, S. (1999). Public Attitudes towards advertising: More favorable than you think. Journal of Advertising Research, 38 (4), 34 - 54.

Shavitt, S., P. Lowery and J. Haefner (1998). Public Attitudes Towards Advertising: More Favourable Than You Might Think. Journal of Advertising Research, 38 (4), 7 - 22.

Siau, K. S. (2003). Building Customer Trust in Mobile Commerce. Communications of the ACM, 46(4), 91 - 94. http://dx.doi.org/10.1145/641205.641211

Spero I, S. M. (2004). Agents of change: how young consumers are changing the world of marketing. Qualatative Market Research, 7(2), 153.

Stewart, D. P. (2002). From Consumer Response to Active Consumer: Measuring the Effectiveness of Interactive Media. Journal of the Academy of Marketing Science, 376 - 396.

Tezinde, T. S. (2002). Getting permission: Exploring factors affecting permission marketing. Journal of Interactive Marketing, 19 (1), $62-73$.

The Jordan Times (November 22, 2009). Mobile phone penetration.

Tsang, M.M, S. Ho, and T., Liang (2004). Consumers attiutude toward Mobile advertising: an Empirical Study. International Journal of Electronic Commerece, 8 (3), 65 - 78.

Varshney, U. (2003). Location Management for Mobile commerce Applications in wireless Internet Environment. ACM Transactions on Internet Technology, $3 \quad$ (3), $236-255$. http://dx.doi.org/10.1145/857166.857169

Ververidis, C. A. (2002). Mobile marketing using location - based services. Proceedings of the First International Conference on Mobile Business, Athens, Greece.

Yang. (2007). Exploring factors affecting consumer intetion to use mobile advertising in Taiwan. Journal of International Marketing, 20 (1), 33 - 49.

Yoon, S. J., and Kim, J. K. (2001). Is the Internet more effective than traditional media? Factors affecting the choice of media. Journal of Advertising Research, 41, 6, 53- 60.

Zanot, E. (1981). Public attitudes towards advertising,In H.H. Keith (ed.). Advertising in a New Age: American Academy of Advertising Proceedings. Provo, UT: American Academy of Advertising.

Zonat, E. (1984). Public attitudes toward advertising: The American experience. International Journal of Advertising, 13, 3 - 15.

Zyman S., \& Broot A. (2002). The end of advertising as we know it. NewJersey: John wiley.

Table 1. Distribution of the study sample according to demographic variables

\begin{tabular}{|l|c|c|}
\hline Variable & Count & Percentage (\%) \\
\hline Gender & 69 & 53 \\
Male & 61 & 47 \\
Female & & \\
\hline Age & 37 & 28 \\
$<20$ & 35 & 27 \\
$21-30$ & 23 & 18 \\
$31-40$ & 20 & 15 \\
$41-50$ & 15 & 12 \\
$>51$ & & 14 \\
\hline Education & 18 & 23 \\
Primary & 30 & 46 \\
High school & 60 & 17 \\
Undergraduate & 22 & \\
Graduate & & $\mathbf{1 0 0}$ \\
\hline Total (130 respondents) & & \\
\hline
\end{tabular}


Table 2. Cronbach's alpha Values of the constructs

\begin{tabular}{|l|c|}
\hline Constructs & Over all attitude \\
\hline Entertainment & 0.9010 \\
\hline Informativeness & 0.8311 \\
\hline Irritation & 0.8102 \\
\hline Credibility & 0.779 \\
\hline
\end{tabular}

Table 3. Correlation coefficients values of the constructs

\begin{tabular}{|l|l|c|}
\hline \multicolumn{1}{|c|}{} & Entertainment \\
\hline Overall attitude & Correlation Coefficient & $0.625^{* *}$ \\
& Sig ( 1 - tailed ) & 0.000 \\
\cline { 2 - 3 } & & Informativeness \\
\cline { 2 - 3 } & Correlation Coefficient & $0.654^{* *}$ \\
& Sig ( 1 -tailed ) & 0.000 \\
\cline { 2 - 3 } & & Irritation \\
\cline { 2 - 3 } & Correlation Coefficient & $-0.13^{* *}$ \\
& Sig ( 1 -tailed ) & $0.019^{*}$ \\
\cline { 2 - 3 } & & Credibility \\
\cline { 2 - 3 } & Correlation Coefficient & $0.640^{* *}$ \\
& Sig ( 1 tailed ) & 0.000 \\
\hline & & Age \\
\hline & Correlation Coefficient & -0.51 \\
& Sig ( 1 - tailed ) & 0.01 \\
\hline & & Gender \\
\hline & Correlation Coefficient & $\mathrm{P}=0.72$ \\
& Sig ( 1- tailed ) & $\mathrm{P}=0.84$ \\
\hline & & Education \\
\hline & Correlation Coefficient & 0.74 \\
& sig ( 1 -tailed ) & 0.035 \\
\hline & & \\
\hline
\end{tabular}

Note: (1) The analysis of gender differences was conducted via a t-test.

Table 4. Results of regression analysis $\left(\mathrm{p}^{*}<0.05, \mathrm{p}^{* *}<0.001\right)$

\begin{tabular}{|l|c|c|c|c|c|}
\hline Construct & $\boldsymbol{\beta}$ & $\mathbf{R}^{\mathbf{2}}$ & $\boldsymbol{\Delta} \mathbf{R}^{\mathbf{2}}$ & $\mathbf{t}$ & $\boldsymbol{\rho}$ \\
\hline Entertainment & 0.675 & 0.455 & 0.455 & 17.77 & $0.0000^{* *}$ \\
\hline Credibility & 0.365 & 0.541 & 0.087 & 8.47 & $0.0000^{* *}$ \\
\hline Irritation & -0.162 & 0.561 & 0.006 & -4.09 & $0.0000^{* *}$ \\
\hline Informativeness & 0.114 & 0.568 & 0.019 & 2.35 & $0.019^{*}$ \\
\hline
\end{tabular}

Table 5. Number of SMS messages sent and received by the respondents (per day\%)

\begin{tabular}{|l|c|c|}
\hline Number of SMS messages & Sent ( \%) & Received (\%) \\
\hline 1 & 37.8 & 33.9 \\
\hline $2-3$ & 27.7 & 31.3 \\
\hline $4-5$ & 18.3 & 18.7 \\
\hline More than 5 & 16.2 & 16.1 \\
\hline Total ( 130 respondents ) & $\mathbf{1 0 0} \%$ & $\mathbf{1 0 0 \%}$ \\
\hline
\end{tabular}




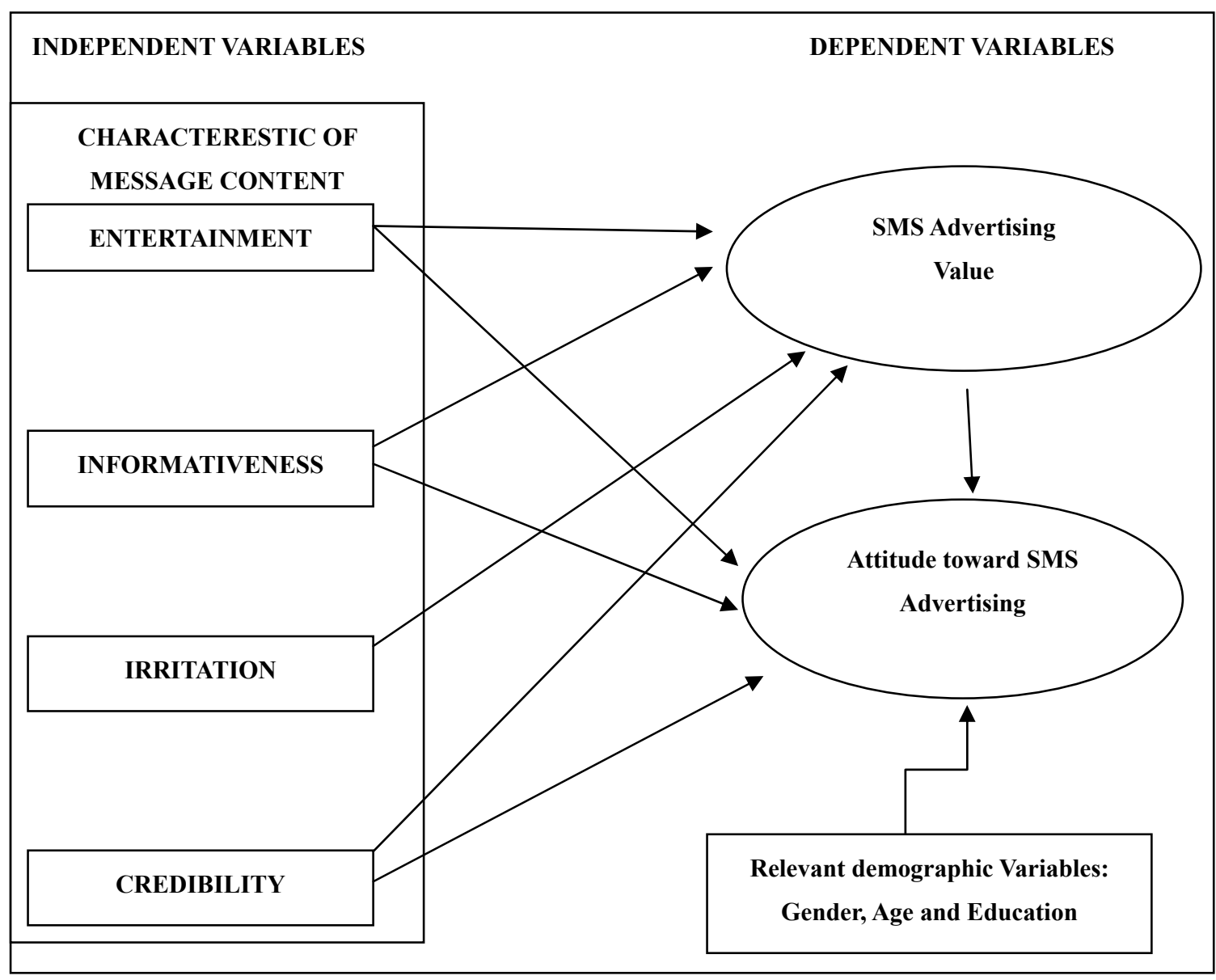

Figure 1. Model for testing consumer attitudes towards SMS advertisements Source: Adapted from Brackett and Carr (2001).

\section{APPENDIX:}

\section{Appendix 1: Questionnaire}

The following are the questions used to collect data in this study:

\section{Entertainment}

I feel that receiving mobile advertisements is enjoyable and entertaining

I find mobile advertising is pleasant

I find entertainment services (video, game, images,) positive

\section{Informativeness}

I feel that receiving mobile advertising is a good source of timely information

Mobile advertisements provide the information on a product or service that Iam looking to use and need

Through advertising messages via mobile phone, I receive exclusive information

\section{Irritation}

I feel that mobile advertising is irritating

I feel that mobile advertisements are almost everywhere

Contents in mobile advertisements are often annoying

Iam comfortable with accepting advertising messages on my mobile phone 


\section{Credibility}

I use mobile advertising as a reference for purchasing.

I think it is inevitable that mobile phones will become an advertising tool in the future

I trust Mobile advertising.

I would accept mobile advertising messages if I was given financial incentives

\section{Attitude}

Over all, I like mobile Advertising, and accept that SMS advertising is better than the traditional ways of advertising. 